\title{
Article \\ Observed Methane Uptake and Emissions at the Ecosystem Scale and Environmental Controls in a Subtropical Forest
}

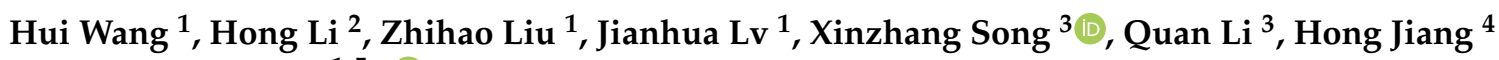 \\ and Changhui Peng ${ }^{1,5, *(D)}$
}

1 Center for Ecological Forecasting and Global Change, College of Forestry, Northwest A\&F University, Yangling 712100, China; 2016060224@nwafu.edu.cn (H.W.); zhihaoliu@nwafu.edu.cn (Z.L.); 2018060235@nwafu.edu.cn (J.L.)

2 Faculty of Architecture and Urban Planning, Chongqing University, Chongqing 400045, China; lihom@cqu.edu.cn

3 State Key Laboratory of Subtropical Silviculture, Zhejiang A\&F University, Hangzhou 311300, China; songxinzhang@gmail.com (X.S.); 2017060240@nwafu.edu.cn (Q.L.)

4 International Institute for Earth System Science, Nanjing University, Nanjing 210023, China; jianghong@nju.edu.cn

5 Department of Biology Sciences, Institute of Environment Sciences, University of Quebec at Montreal, Montreal, QC H3C 3P8, Canada

* Correspondence: peng.changhui@uqam.ca; Tel.: +86-029-87080608

Citation: Wang, H.; Li, H.; Liu, Z.; Lv, J.; Song, X.; Li, Q.; Jiang, H.; Peng, C. Observed Methane Uptake and

Emissions at the Ecosystem Scale and Environmental Controls in a Subtropical Forest. Land 2021, 10, 975 https://doi.org/10.3390/ land10090975

Academic Editor: Heiko Balzter

Received: 28 July 2021

Accepted: 10 September 2021

Published: 16 September 2021

Publisher's Note: MDPI stays neutral with regard to jurisdictional claims in published maps and institutional affiliations.

Copyright: (c) 2021 by the authors. Licensee MDPI, Basel, Switzerland. This article is an open access article distributed under the terms and conditions of the Creative Commons Attribution (CC BY) license (https:// creativecommons.org/licenses/by/ $4.0 /)$.
Abstract: Methane $\left(\mathrm{CH}_{4}\right)$ is one of the three most important greenhouse gases. To date, observations of ecosystem-scale methane $\left(\mathrm{CH}_{4}\right)$ fluxes in forests are currently lacking in the global $\mathrm{CH}_{4}$ budget. The environmental factors controlling $\mathrm{CH}_{4}$ flux dynamics remain poorly understood at the ecosystem scale. In this study, we used a state-of-the-art eddy covariance technique to continuously measure the $\mathrm{CH}_{4}$ flux from 2016 to 2018 in a subtropical forest of Zhejiang Province in China, quantify the annual $\mathrm{CH}_{4}$ budget and investigate its control factors. We found that the total annual $\mathrm{CH}_{4}$ budget was $1.15 \pm 0.28 \sim 4.79 \pm 0.49 \mathrm{~g} \mathrm{CH}_{4} \mathrm{~m}^{-2}$ year ${ }^{-1}$ for 2017-2018. The daily $\mathrm{CH}_{4}$ flux reached an emission peak of $0.145 \mathrm{~g} \mathrm{~m}^{-2} \mathrm{~d}^{-1}$ during winter and an uptake peak of $-0.142 \mathrm{~g} \mathrm{~m}^{-2} \mathrm{~d}^{-1}$ in summer. During the whole study period, the studied forest region acted as a $\mathrm{CH}_{4}$ source $(78.65 \%)$ during winter and a sink $(21.35 \%)$ in summer. Soil temperature had a negative relationship $\left(p<0.01 ; \mathrm{R}^{2}=0.344\right)$ with $\mathrm{CH}_{4}$ flux but had a positive relationship with soil moisture $\left(p<0.01 ; R^{2}=0.348\right)$. Our results showed that soil temperature and moisture were the most important factors controlling the ecosystem-scale $\mathrm{CH}_{4}$ flux dynamics of subtropical forests in the Tianmu Mountain Nature Reserve in Zhejiang Province, China. Subtropical forest ecosystems in China acted as a net source of methane emissions from 2016 to 2018, providing positive feedback to global climate warming.

Keywords: $\mathrm{CH}_{4}$ flux; eddy covariance; annual budget; soil temperature; soil moisture

\section{Introduction}

Methane $\left(\mathrm{CH}_{4}\right)$ is an important greenhouse gas and accounts for approximately $32 \%$ of the global radiative forcing. It has 28-32 times higher global warming potential over a 100-year time horizon than does carbon dioxide $\left(\mathrm{CO}_{2}\right)$ [1,2]. The atmospheric $\mathrm{CH}_{4}$ concentration has been increasing and has more than doubled since preindustrial times, showing a rapid increase until 1999, after which it remained nearly constant until 2006. From 2007, the atmospheric $\mathrm{CH}_{4}$ concentration again began increasing, likely due to a combination of anomalously high temperatures in the Arctic region and more precipitation in tropical regions [3]. Although major $\mathrm{CH}_{4}$ sources (e.g., wetlands, rice paddies, biomass burning, and fossil fuels) have been identified [4], we still lack a complete understanding of ecosystem-specific information on $\mathrm{CH}_{4}$ sinks and sources that could be significant factors contributing to global variations in $\mathrm{CH}_{4}$ sinks and sources $[2,5,6]$. 
Upland forest soils are the main biological $\mathrm{CH}_{4}$ sink [6,7]; however, forests may produce and emit $\mathrm{CH}_{4}$, especially in wet, warm climates [8], and forest soil $\mathrm{CH}_{4}$ uptake may decline with increases in precipitation [9]. Subtropical forests, as an important part of forest ecosystems, are rich in tree species, characterized by complex stand structures and various environmental conditions [10-12], and they play an important role in the global greenhouse gas budget $[2,5,11]$. To date, investigations on the dynamics of $\mathrm{CH}_{4}$ fluxes in subtropical upland forests and their controlling factors at the ecosystem scale are still lacking [13]. Therefore, it is important to understand $\mathrm{CH}_{4}$ sinks and sources in subtropical forest ecosystems and $\mathrm{CH}_{4}$ exchange between the atmosphere and forests.

Many studies have identified mechanisms controlling methane emissions and uptake, including the water table [13-16], soil temperature [13,17], soil redox potential [8], atmospheric pressure [8,13], water vapor deficiency [17], ecosystem respiration [15,18], photosynthesis [19,20], ecosystem disturbances [13] and management practices [13]. In fact, soil temperature [21-24] and soil water content [22-26] appear to be the primary factors controlling $\mathrm{CH}_{4}$ emissions. Methane production, which is a microbial-mediated reaction, can be accelerated by higher temperatures. High temperatures increase not only $\mathrm{CH}_{4}$ production by increasing the metabolic activities of microorganisms and plants $[27,28]$ but also conductance for methane diffusion and plant-mediated transport [29], which enhances release processes and can lead to higher methane emissions. In addition, methanotrophs in the soil can consume $\mathrm{CH}_{4}$ by microbial oxidation [30]. Although temperature has an effect on both methanogens and methanotrophs, methanogenesis seems to be more sensitive than methanotrophy to soil temperature [31]. Water content has been one of the most important drivers of $\mathrm{CH}_{4}$ flux, as it can regulate the oxygen availability and the relative thickness of the aerobic and anaerobic zones for $\mathrm{CH}_{4}$ oxidation and production, respectively [32]. In both temperate mixed forest ecoregions and alpine meadow and forest ecoregions, it was found that secondary forests had relatively lower $\mathrm{CH}_{4}$ uptake than did natural forests in the corresponding area due to the lower soil water content in natural forests [33-35]. To date, we still lack ecosystem-scale in-depth studies about the influence mechanism of temperature and soil water content on $\mathrm{CH}_{4}$ sinks and sources in subtropical forests.

Many previous investigations and analyses on upland forest soil $\mathrm{CH}_{4}$ were based on the results of experiments carried out using the manual static chamber method [13,36-39]. The focus on soil fluxes reflects the difficulty of enclosing whole trees in static chambers. However, the coverage area of the static chamber method is small (from $\mathrm{cm}^{-2}$ to $\mathrm{m}^{-2}$ ), and the measurement frequency of this method is very low. The eddy covariance (EC) technique, which is based on the micrometeorological method and continuously measures the vertical concentration gradients of gases, provides a cutting-edge method to continuously measure and quantify key ecosystem greenhouse gas fluxes (such as $\mathrm{CO}_{2}$ and $\mathrm{CH}_{4}$ ) with detailed information on short-term variations in flux at the ecosystem scale [13,40,41]. To date, the EC technique has been applied in the investigation of $\mathrm{CH}_{4}$ flux and the annual budget for a variety of different ecosystems, including wetlands [42-44], peatlands [45-47], rice paddies [48,49] and forests [38,50-52]. Although more than 200 EC sites have been established worldwide with $\mathrm{CH}_{4}$ flux measurements [51], there is no study that reports $\mathrm{CH}_{4}$ flux in subtropical forests in China using the EC method [13].

In this study, we conducted and observed three years of EC measurements of ecosystemscale $\mathrm{CH}_{4}$ flux from a subtropical forest in Zhejiang Province, China. The main objectives of this study were to (1) investigate and analyze the diurnal and seasonal variations in the characteristics of $\mathrm{CH}_{4}$ fluxes; (2) quantify the annual budget of $\mathrm{CH}_{4}$ fluxes and the contribution of different seasonal $\mathrm{CH}_{4}$ fluxes to the annual budget; and (3) explore the controlling factors of subtropical forest $\mathrm{CH}_{4}$ emissions and uptake at the ecosystem scale. 


\section{Materials and Methods}

\subsection{Site Description}

The studied subtropical forest was located in the Tianmu Mountain Nature Reserve, northwest of Lin'an District, Zhejiang Province, China $\left(30^{\circ} 20^{\prime} 34.951^{\prime \prime} \mathrm{N}, 119^{\circ} 26^{\prime} 08.671^{\prime \prime} \mathrm{E}\right.$, Figure 1). This area has a subtropical monsoon climate, with an elevation of $1152 \mathrm{~m}$. The annual mean temperature and the annual total precipitation were $11.9^{\circ} \mathrm{C}$ and $1715 \mathrm{~mm}$ from 2016 to 2018, respectively. The region is covered by 140-year-old natural evergreen and deciduous broad-leaved forests. The dominant plants are Cyclobalanopsismyrsinifolia, Daphniphyllummacropodum and Pterostyraxcorymbosus. The canopy height, forest density and forest crown closure were $15-20 \mathrm{~m}, 3125 \mathrm{hm}^{-2}$ and 0.7 , respectively.

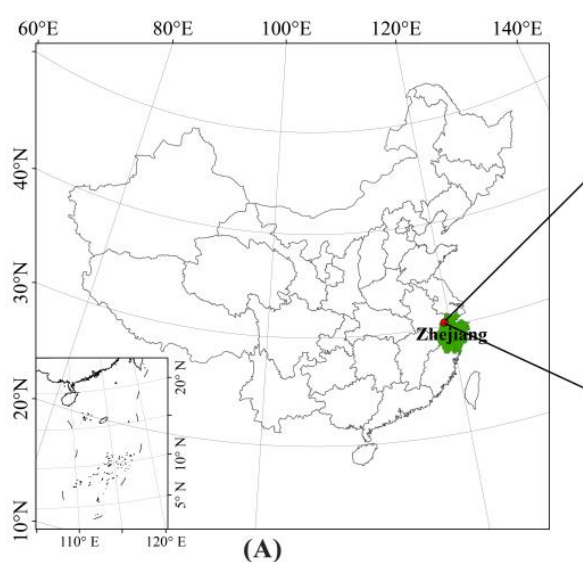

(A)

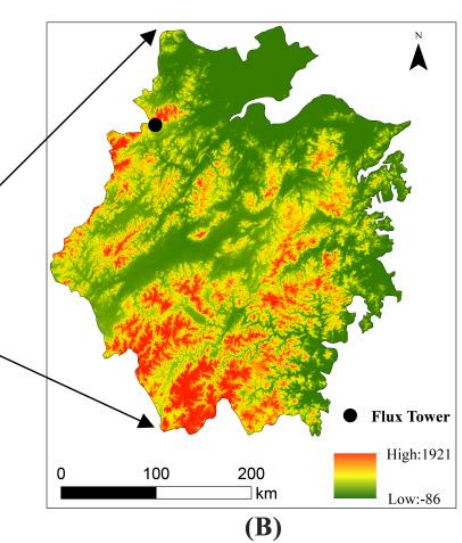

(B)

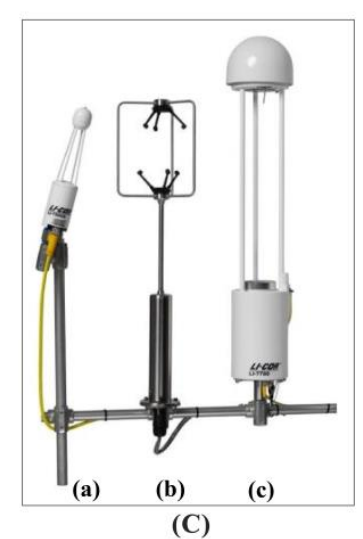

(C)

Figure 1. (A) Site location on a map of China. (B) Topography of the study region. (C) Eddy covariance system of the study site including (a) LI-7500A-an open-path $\mathrm{CO}_{2} / \mathrm{H}_{2} \mathrm{O}$ infrared gas analyzer, (b) WindMaster-a sonic anemometer and (c) LI-7700-an open-path $\mathrm{CH}_{4}$ infrared gas analyzer.

\subsection{Eddy Covariance System}

The eddy covariance (EC) technique was used to measure and quantify $\mathrm{CH}_{4}$ flux from 2016 to 2018 . The EC system was installed in a relatively flat region. Sensors were mounted $38 \mathrm{~m}$ above the soil surface. Sensor height was determined to ensure that the EC system was mounted at least twice the height of the plant canopy $(15-20 \mathrm{~m})$ during the peak growing season. The EC system included an open-path $\mathrm{CH}_{4}$ infrared gas analyzer (LI-7700, LI-COR Biosciences, Lincoln, NE, USA), an open-path $\mathrm{CO}_{2} / \mathrm{H}_{2} \mathrm{O}$ infrared gas analyzer (LI-7500A, LI-COR) and a sonic anemometer (WindMaster, Gill instruments, Lymington, UK). All raw data were collected at a frequency of $10 \mathrm{~Hz}$ and stored by a data logger (LI-7550, LI-COR). Data between 27 February and 30 June in 2016 were missing due to a lack of electrical power supply.

\subsection{Data Processing}

The $\mathrm{CH}_{4}$ flux of 30-min block averages was calculated by EddyPro software (version 6.2.0, LI-COR Biosciences, Lincoln, NE, USA). We used several advanced settings during processing. The angle of attack corrections for Gill WindMaster Pro firmware were used [53] and the block average method was used for detrending raw data. The time lag detection method we used was covariance maximization with default. The double coordinate rotation method was used to ensure that the mean vertical wind speed was zero, averaged over $30 \mathrm{~min}$. The compensation of density fluctuations (WPL terms) was implemented according to Webb et al. [54]. The steady state test and the well-developed turbulence test provided a quality flag (1 9) [55]. We applied spike detection of raw data after Vickers and Mahrt [56].

After data processing by EddyPro, we further filtered the dataset to ensure data quality. We discarded the data when rainfall occurred. $\mathrm{CH}_{4}$ flux was used only when the relative signal strength indicator (RSSI) was $>20 \%$. In addition, we filtered the $\mathrm{CH}_{4}$ flux using a 
threshold of $\mathrm{u}^{*}>0.3 \mathrm{~m} \mathrm{~s}^{-1}$ to ensure well-developed atmospheric mixing conditions [57]. According to the study of Foken et al. [55], the quality of fluxes was classified by the quality flags of " 0 ", " 1 " and " 2 ", which represent high-quality data, intermediate-quality fluxes and poor-quality fluxes, respectively. Data with quality flags of "2" were not used for further analysis. These quality criteria occasionally caused equipment failures, resulting in data intervals of different durations.

After the quality check, $31.8 \%$ of the raw data were left for analyses. We obtained the daily $\mathrm{CH}_{4}$ flux by averaging the quality-controlled half-hourly $\mathrm{CH}_{4}$ flux for each day. Because of quality control, the amount of data remaining varied greatly from day to day. For reliable daily averaged $\mathrm{CH}_{4}$ flux, only the days with more than 6 data points were used for analyses.

To estimate the budget of the $\mathrm{CH}_{4}$ flux, missing data needed to be interpolated. The random forest (RF) method was used to fill the gaps in the data. The RF algorithm introduced by Breiman [58] is an ensemble method of regression trees. Kim et al. [59] tested $\mathrm{RF}$ for eddy flux gap filling at several sites and found that it outperformed other techniques for all sites and all gap conditions. Thus, we used the RF exactly following Kim et al. [59]. The following variables were used as potential drivers of $\mathrm{CH}_{4}$ to train the RF: sensible heat flux $(\mathrm{H})$, net ecosystem exchange (NEE), latent heat flux (LE), gross ecosystem product (GEP), soil temperature at $10 \mathrm{~cm}$ deep $\left(\mathrm{T}_{\text {soil } 10}\right)$, air temperature $(\mathrm{Ta})$, relative humidity $(\mathrm{RH})$, pressure $(\mathrm{P})$, vapor pressure deficit $(\mathrm{VPD})$, Ustar, soil moisture at $10 \mathrm{~cm}$ deep $\left(\mathrm{M}_{\text {soil } 10}\right)$ and precipitation. The gap-filling performance of RF method in our study was also very good $\left(R^{2}=0.85\right)$. Then, the gap-filled flux was used for the calculation of the budget. The annual flux was the sum of the daily average flux of the year.

The uncertainties of the $\mathrm{CH}_{4}$ flux include the random uncertainty and uncertainty of gap-filling for the $\mathrm{CH}_{4}$ flux. The random uncertainty for each half-hourly $\mathrm{CH}_{4}$ flux was estimated through the empirical models described by Finkelstein and Sims [60]. The uncertainty of gap-filling for $\mathrm{CH}_{4}$ flux was also estimated following Kim et al. [59].

Meteorological and hydrological conditions were also measured by related sensors, including Ta (WUSH-TW100), RH (DHC2), precipitation (SL3-1), $\mathrm{T}_{\text {soil } 10}$ (ZQZ-TW) and $\mathrm{M}_{\text {soil 10 }}(\mathrm{DZN} 3)$.

\section{Results}

\subsection{Temporal Variations in Environmental Variables}

Both soil temperature and soil moisture showed distinct seasonal variations (Figure 2a,b). Daily soil temperature also showed a distinct seasonal variation, with a minimum temperature of $0.9^{\circ} \mathrm{C}$ in winter and a maximum temperature of $35.9^{\circ} \mathrm{C}$ in summer. The annual mean soil temperature showed small interannual variability ranging from 18.5 to $18.9^{\circ} \mathrm{C}$. In contrast to soil temperature, soil moisture was low in summer and high in winter during the three-year measurement period. For example, daily soil moisture decreased from June and reached the lowest value of $19.5 \%$ in August 2016. Then, it increased until October to about 2.5\% and maintained a relatively steady state. Most of the rainfall occurred in summer during the measurement period. Annual rainfall was highest in 2016 and lowest in 2017. The annual rainfall totals in 2016, 2017 and 2018 were 2088, 1381 and $1677 \mathrm{~mm}$, respectively.

\subsection{Diurnal Variationsin $\mathrm{CH}_{4}$ Flux}

Diel patterns of $\mathrm{CH}_{4}$ flux varied among different seasons (Figure 3). The diurnal patterns between winter and summer obviously showed a contrast, although there was no consistent diurnal pattern during spring and fall. In winter, the $\mathrm{CH}_{4}$ flux started to increase after sunrise (7:30) and reached peaks $\left(0.0492,0.0907\right.$ and $0.0606 \mu \mathrm{mol} \mathrm{m}{ }^{-2} \mathrm{~s}^{-1}$ in 2016-2018, respectively) at 10:00-12:00. The diurnal pattern with a noon peak in winter was generally consistent for each year. In contrast to the winter values, the $\mathrm{CH}_{4}$ flux at noon in summer had the lowest daily values. After 8:00 am, the $\mathrm{CH}_{4}$ flux gradually decreased to negative and reached uptake peaks $\left(-0.112,-0.0685\right.$ and $-0.1053 \mu \mathrm{mol} \mathrm{m}^{-2} \mathrm{~s}^{-1}$ in 2016-2018, respectively) at noon (11:30-13:00). 


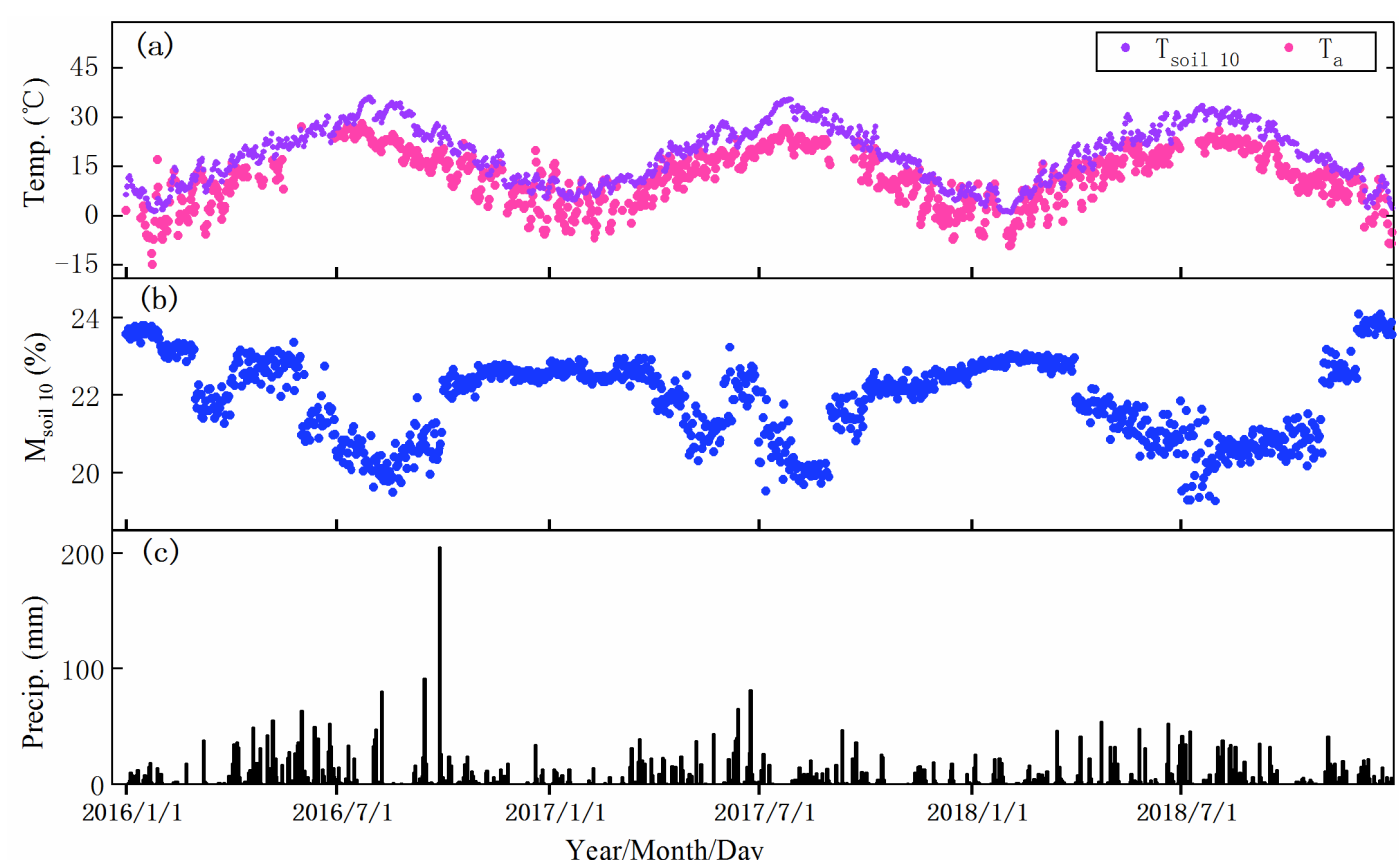

Figure 2. Daily average of environmental variables at the subtropical forest site during the study period, including air temperature ((a), $\mathrm{T}_{\mathrm{a}}$, pink), soil temperature at $10 \mathrm{~cm}$ depth $\left((\mathbf{a}), \mathrm{T}_{\text {soil 10 }}\right.$, purple), soil moisture $\left((\mathbf{b}), \mathrm{M}_{\text {soil 10 }}\right.$, blue $)$ at $10 \mathrm{~cm}$ depth and precipitation $((\mathbf{c}), \mathrm{mm})$.

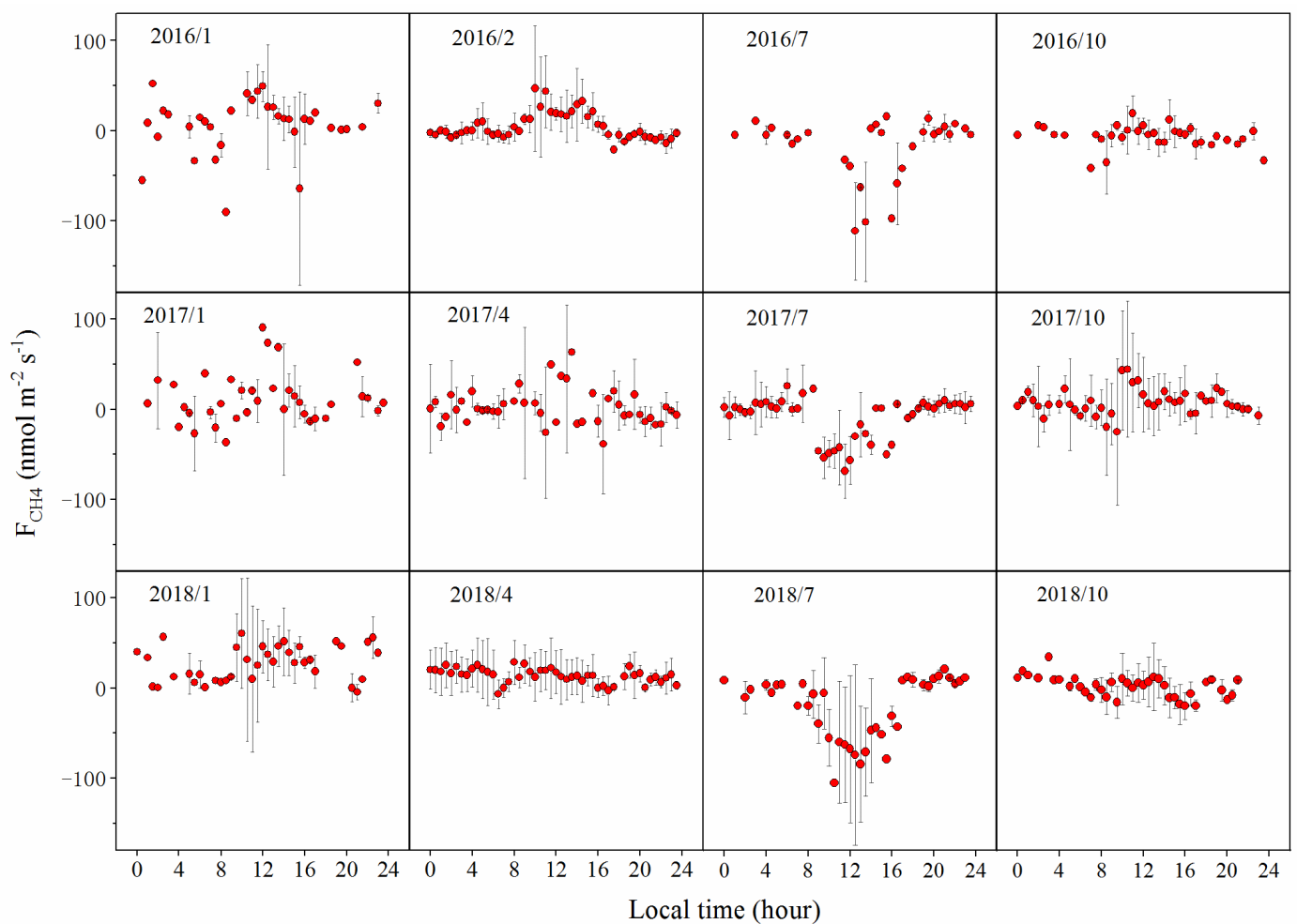

Figure 3. The diurnal pattern of ecosystem-scale $\mathrm{CH}_{4}$ flux from the subtropical forest in different seasons during $2016-2018$. The red points show the average half-hourly flux at the same time in the month. January, April, July and October of each year represent the four seasons of spring, summer, autumn and winter. The data in February were used for spring 2016, as data from March to June were missing due to a lack of electrical power supply. 


\subsection{Seasonal Variations in $\mathrm{CH}_{4}$ Flux}

Large seasonal variations in daily $\mathrm{CH}_{4}$ flux were observed (Figure 4). The daily averaged $\mathrm{CH}_{4}$ flux ranged from -0.142 to $0.145 \mathrm{~g} \mathrm{~m}^{-2}$ day $^{-1}$. The $\mathrm{CH}_{4}$ flux started to decrease in winter (emission) each year and reached the minimum (uptake) in summer. Then, the $\mathrm{CH}_{4}$ flux continuously increased from negative to positive and reached the maximum emissions in winter. The maximum emissions were $0.045 \mathrm{~g} \mathrm{~m}^{-2}$ day $^{-1}$ on 16 January 2016, $0.092 \mathrm{~g} \mathrm{~m}^{-2}$ day $^{-1}$ on 27 November 2017 and $0.145 \mathrm{~g} \mathrm{~m}^{-2}$ day $^{-1}$ on 4 September 2018. Overall, the $\mathrm{CH}_{4}$ flux showed uptake in summer and emission in winter (Figure 4).

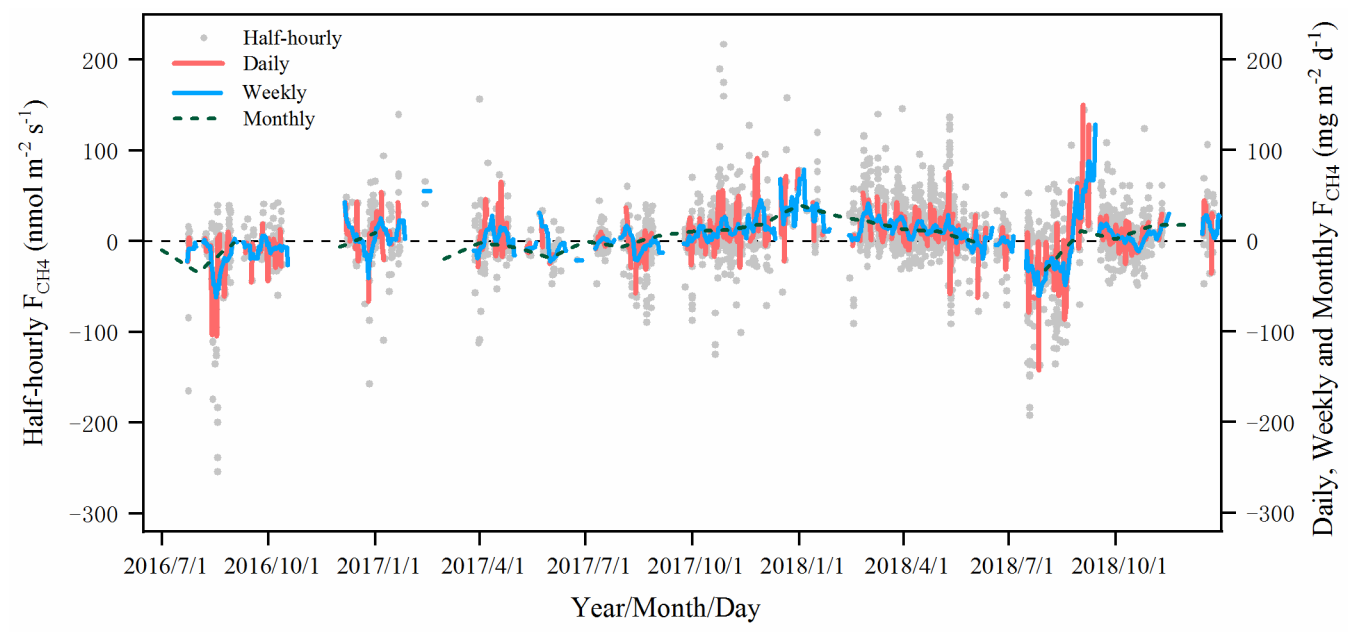

Figure 4. Time series of half-hourly (gray circles), daily (red lines), weekly (blue lines) and monthly (dotted line) $\mathrm{CH}_{4}$ fluxes from 2016 to 2018.

\subsection{Annual Budget of $\mathrm{CH}_{4}$ Flux}

The study site acted as a net source of $\mathrm{CH}_{4}$ during the measurement period of 2017-2018 (Figure 5). Although the $\mathrm{CH}_{4}$ flux in summer was negative in 2017 and 2018, the net budget of the $\mathrm{CH}_{4}$ flux was still positive each year due to the larger contribution of total emissions in winter surpassing the uptake of $\mathrm{CH}_{4}$ in summer. The emissions in 2017 and 2018 accounted for $69.31 \%$ and $87.84 \%$, respectively, while the uptake of $\mathrm{CH}_{4}$ in 2017 and 2018 was only $30.69 \%$ and $12.16 \%$, respectively. In total, the annual budgets of the $\mathrm{CH}_{4}$ flux for 2017 and 2018 were $1.15 \pm 0.28$ and $4.79 \pm 0.49 \mathrm{~g} \mathrm{CH}_{4} \mathrm{~m}^{-2}$ year ${ }^{-1}$, respectively (Figure 5).

\subsection{Environmental Controls on $\mathrm{CH}_{4}$ Flux}

The linear relationship between daily $\mathrm{CH}_{4}$ flux and all environmental factors (including: $\mathrm{Ta}, \mathrm{RH}$, precipitation, $\mathrm{VPD}, \mathrm{T}_{\text {soil 10 }}, \mathrm{M}_{\text {soil 10 }}$ ) we measured was not significant. The monthly averaged $\mathrm{CH}_{4}$ flux exhibited a significant negative linear correlation with soil temperature (Figure $6 \mathrm{a}, p<0.01, \mathrm{R}^{2}=0.34$ ) but increased exponentially with soil moisture (Figure $6 \mathrm{~b}, p<0.01, \mathrm{R}^{2}=0.35$ ). Regression models for the monthly averaged $\mathrm{F}_{\mathrm{CH} 4}$ and soil temperature $\left(\mathrm{T}_{\text {soil 10 }}\right)$ and soil moisture $\left(\mathrm{M}_{\text {soil 10 }}\right)$ are as follows:

$$
\begin{gathered}
\mathrm{F}_{\mathrm{CH} 4}=0.024-0.001 \times \mathrm{T}_{\text {soil } 10} \\
\mathrm{~F}_{\mathrm{CH} 4}=0.013-1.5 \times 10^{\wedge}(-7) \times \mathrm{e}^{\wedge}\left(-0.99 \times \mathrm{M}_{\text {soil 10 }}\right)
\end{gathered}
$$




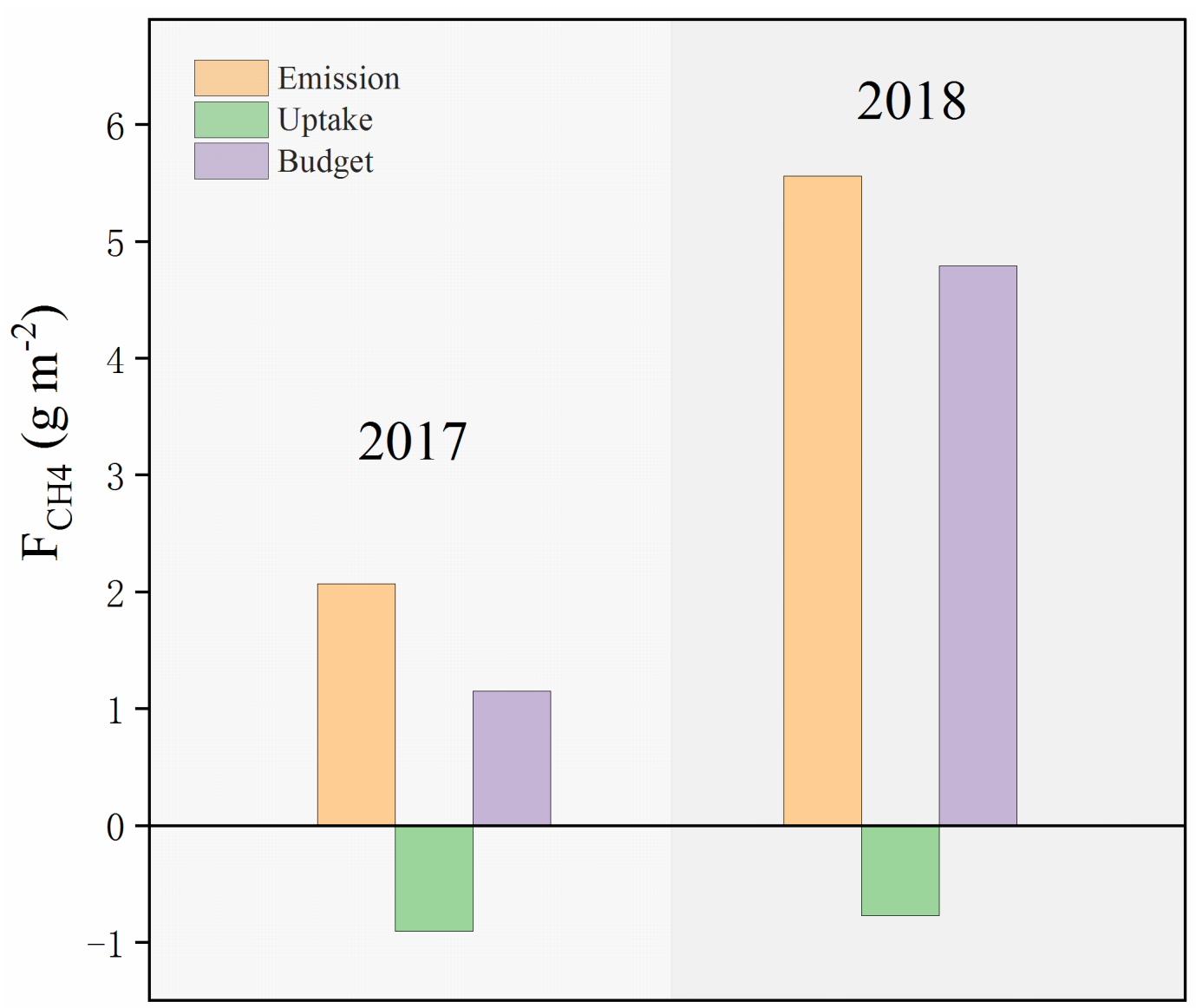

Figure 5. Annual emissions, uptake and net budget $\left(\mathrm{g} \mathrm{m}^{-2}\right)$ of $\mathrm{CH}_{4}$ flux in 2017 and 2018. Emissions represent the sum of all positive fluxes in the year, and uptake represents the sum of all negative fluxes. The net budget is the sum of emissions and uptake.

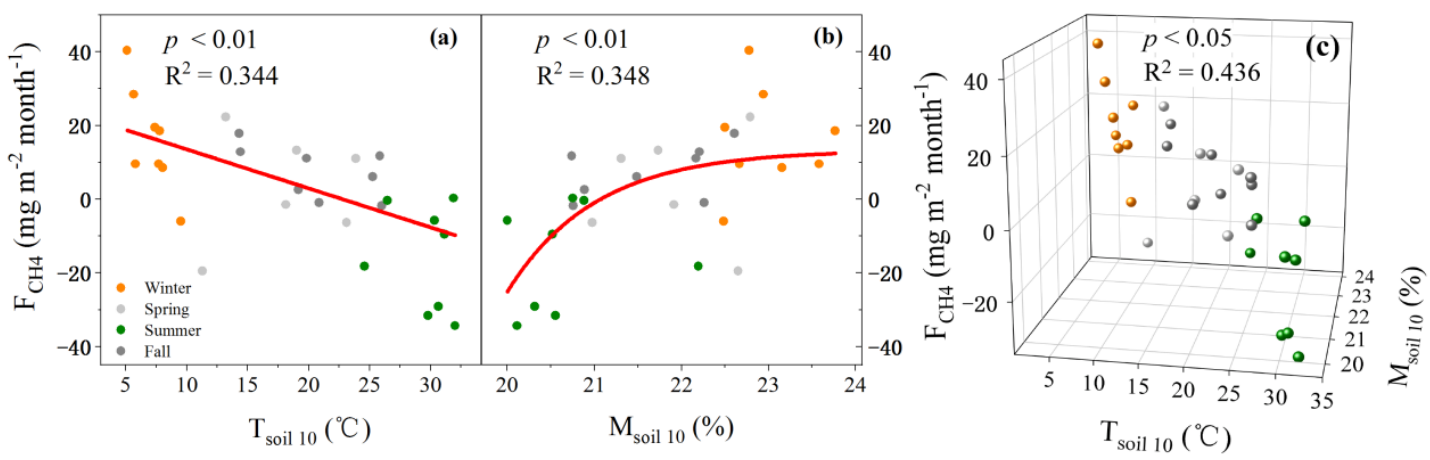

Figure 6. Correlations between monthly $\mathrm{CH}_{4}$ flux $\left(\mathrm{mg} \mathrm{m}^{-2} \mathrm{month}^{-1}\right)$ and (a) soil temperature at $10 \mathrm{~cm}$ of soil depth $\left(\mathrm{T}_{\text {soil 10 }}\right)$ and (b) soil moisture at $10 \mathrm{~cm}$ soil depth $\left(\mathrm{M}_{\text {soil 10 }}\right)$ and the three-dimensional scatter plot (c) between monthly $\mathrm{CH}_{4}$ flux and $\mathrm{T}_{\text {soil } 10}$ and $\mathrm{M}_{\text {soil } 10}$.

The combination of $\mathrm{T}_{\text {soil } 10}$ and $\mathrm{M}_{\text {soil } 10}$ explained more of the variation in the $\mathrm{CH}_{4}$ flux (Figure $6 c, R^{2}=0.44$ ). The three-dimensional fitting equation for the combined effect (c) of soil temperature and moisture on $\mathrm{CH}_{4}$ flux is as follows:

$$
\mathrm{F}_{\mathrm{CH} 4}=10648 \times\left(11389-483 \times \mathrm{T}_{\text {soil 10 }}\right) \times\left[1.52+10981 \times \mathrm{e}^{\wedge}\left(-1.54 \times \mathrm{M}_{\text {soil 10 }}\right)\right]
$$

With the increase in soil temperature and the synchronous decrease in soil moisture, the $\mathrm{CH}_{4}$ flux gradually decreased from positive (emissions) in winter (Figure 6c, yellow points) to negative (uptake) in summer (Figure 6c, green points). 


\section{Discussion}

\subsection{Temporal Variations and Annual Budget of $\mathrm{CH}_{4}$ Flux}

The diurnal patterns with a single uptake peak and emissions peak, which all appeared at noon, occurred in summer and winter, respectively, each year in this study. A diurnal pattern of $\mathrm{CH}_{4}$ flux with an uptake peak occurring around noon (10:00 am-14:00 pm) in summer has often been observed in upland forests [61-63]. Another diurnal pattern of emission peaks occurring in winter has rarely been reported for upland forests [64] but has been well reported for wetlands $[44,65,66]$. Additionally, a phenomenon similar to that in this study, where both of the two diurnal patterns occurred in summer and winter respectively each year, has not been reported in upland forests. Meanwhile, both diurnal variations can randomly or sporadically occur in an ecosystem [65,67].

The seasonal variation pattern of $\mathrm{CH}_{4}$ uptake in summer and emission in winter was also found for the first time in upland forests in this study. Even $\mathrm{u}^{*}$ threshold filtering was not used, the seasonal dynamic was similar to the original result. The range of daily $\mathrm{CH}_{4}$ flux in this study was $-142 \sim 145 \mathrm{mg} \mathrm{m}^{-2}$ day $^{-1}$. The uptake range was approximately 10 times higher than that measured in other forest ecosystems [68,69], mainly because those studies measured only $\mathrm{CH}_{4}$ flux in the soil but not at the ecosystem scale. The pattern of $\mathrm{CH}_{4}$ uptake in summer has often been observed. Wang et al. [63] measured $\mathrm{CH}_{4}$ fluxes from June to October in a temperate forest that reached an uptake peak in September with a range from -0.002 to $-0.006 \mathrm{~g} \mathrm{~m}^{-2} \mathrm{~d}^{-1}$. In addition to the temperate forest system research, a similar pattern of $\mathrm{CH}_{4}$ flux with uptake in summer has been reported in mixed deciduous forests [69], broad-leaved/Korean pine forests [61] and spruce-fir forests [70]. Unlike the uptake pattern in summer, an emissions pattern in winter has rarely been reported. Only Sakabe et al. [67] reported that $\mathrm{CH}_{4}$ emissions occurred in the summer, fall and winter in 2009 in a coniferous forest, mainly due to the increase in precipitation. Except for this example, we did not find a similar pattern in other ecosystems.

The annual budgets of the $\mathrm{CH}_{4}$ flux for 2017 and 2018 were estimated to be $1.15 \pm 0.28$ and $4.79 \pm 0.49 \mathrm{~g} \mathrm{CH}_{4} \mathrm{~m}^{-2}$ year ${ }^{-1}$ in this study, respectively. When $\mathrm{u}^{*}$ threshold filtering was not used, the annual budgets was $0.22 \sim 2.68 \mathrm{~g} \mathrm{CH}_{4} \mathrm{~m}^{-2}$ year ${ }^{-1}$. The range of the annual budget was different from that of other subtropical or tropical ecosystems (Table 1 ) based on the eddy covariance technique [44,52,71]. Shoemaker et al. [52] reported that the budget in spruce-fir forests was an order of magnitude smaller than that in this study. However, in alpine grasslands and mangrove forests [44,71], the budgets were an order of magnitude higher than that in this study. Except for the eddy covariance technique, we compared the range $\left(-142 \sim 145 \mathrm{mg} \mathrm{m}^{-2} \mathrm{~d}^{-1}\right)$ of $\mathrm{CH}_{4}$ daily average flux with other subtropical upland forests (Table 1) in China and found that the range was higher than that of other ecosystems $[35,72,73]$. Except for subtropical or tropical ecosystems, we compared the range $\left(-0.218\right.$ to $-142 \mathrm{mg} \mathrm{m}^{-2}$ day $\left.^{-1}\right)$ of $\mathrm{CH}_{4}$ uptake (sink) at our site with that in temperate forests $[74,75]$ and found that it was higher than that in temperate forests. Smith et al. [75] reported that $\mathrm{CH}_{4}$ uptake ranged from -0.05 to $-3.6 \mathrm{mg} \mathrm{m}^{-2}$ day $^{-1}$ in forests located in six countries of northern Europe. Morishita et al. [74] found that $\mathrm{CH}_{4}$ uptake ranging from -0.05 to $-4.3 \mathrm{mg} \mathrm{C} \mathrm{m}^{-2}$ day $^{-1}$ was observed across 26 forest sites in Japan. According to these comparisons, we found that the subtropical forest can act as a significant $\mathrm{CH}_{4}$ source in upland forests. 
Table 1. Comparison of $\mathrm{CH}_{4}$ budgets in different ecosystems.

\begin{tabular}{|c|c|c|c|c|c|c|c|c|}
\hline Country & Latitude/Longitude & Climate & Ecosystem Type & Methods & Sampling Period & $\begin{array}{l}\text { Daily Average Flux } \\
\left(\mathrm{mg} \mathrm{CH}_{4} \mathrm{~m}^{-2} \mathrm{~d}^{-1}\right)\end{array}$ & $\begin{array}{c}\text { Annual Flux } \\
\left(\mathrm{g} \mathrm{CH}_{4} \mathrm{~m}^{-2} \text { year }^{-1}\right)\end{array}$ & References \\
\hline China & $21^{\circ} 57^{\prime} \mathrm{N}, 101^{\circ} 12^{\prime} \mathrm{E}$ & Tropical & Primary rainforest & Chamber & Dry to wet season & $-0.944 \pm 0.0096$ & & [35] \\
\hline China & $21^{\circ} 55^{\prime} \mathrm{N}, 101^{\circ} 16^{\prime} \mathrm{E}$ & Tropical & Secondary forest & Chamber & Dry to wet season & $-0.8192 \pm 0.0416$ & & [35] \\
\hline China & $23^{\circ} 11^{\prime} \mathrm{N}, 112^{\circ} 33^{\prime} \mathrm{E}$ & Tropical & Forest & Chamber & One year & $-1.24201 \pm 0.3287$ & & [73] \\
\hline China & $23^{\circ} 10^{\prime} \mathrm{N}, 112^{\circ} 33^{\prime} \mathrm{E}$ & Subtropical & Pine-broadleaf forest & Chamber & Every quarter & $-0.44 \pm 0.2133$ & & [72] \\
\hline China & $30^{\circ} 20^{\prime} \mathrm{N}, 119^{\circ} 26^{\prime} \mathrm{E}$ & Subtropical & $\begin{array}{l}\text { evergreen and deciduous } \\
\text { broad-leaved mixed forest }\end{array}$ & $\mathrm{EC}$ & All year & $-142 \sim 145$ & $1.15 \pm 0.28 \sim 4.79 \pm 0.49$ & This study \\
\hline China & $37^{\circ} 35^{\prime} \mathrm{N}, 101^{\circ} 20^{\prime} \mathrm{E}$ & Tibetan plateau & Alpine grassland & $\mathrm{EC}$ & All year & 61.8 & $26.4 \sim 33.8$ & [44] \\
\hline China & $31^{\circ} 31^{\prime} \mathrm{N}, 121^{\circ} 57^{\prime} \mathrm{E}$ & Subtropical & Salt marsh & $\mathrm{EC}$ & All year & $64.383 \pm 10.959$ & $23.5 \pm 4.0$ & [42] \\
\hline China & $22^{\circ} 29^{\prime} \mathrm{N}, 114^{\circ} 01^{\prime} \mathrm{E}$ & Subtropical & Mangrove & $\mathrm{EC}$ & All year & $32.055 \pm 1.096$ & $11.7 \pm 0.4$ & [71] \\
\hline Brazilian & $16^{\circ} 29^{\prime} \mathrm{S}, 120^{\circ} 23^{\prime} \mathrm{E}$ & Tropical & Flooded forest & $\mathrm{EC}$ & All year & 74.246 & 27.1 & [76] \\
\hline
\end{tabular}




\subsection{Control Factors of $\mathrm{CH}_{4}$ Flux}

The annual $\mathrm{CH}_{4}$ budget (net ecosystem exchange) depends on the balance of the $\mathrm{CH}_{4}$ sink (uptake) and source (emissions). Methane uptake and emissions are a combination of biochemical and physical processes [77]. It is widely recognized that $\mathrm{CH}_{4}$ flux dynamics in forest ecosystems are controlled by multiple environmental factors, including soil temperature, soil moisture, soil nutrients, natural disturbances such as droughts and fires, and forest management practices (such as thinning and understorey removal) [13].

Temperature, as a primary driver, plays an important role in affecting $\mathrm{CH}_{4}$ production, oxidation and emissions in various forest ecosystems [47,78-80]. Changes in soil temperature affect not only the activities of soil microbes [81], but also the transport of $\mathrm{CH}_{4}$ flux from soil to the atmosphere $[29,82]$. Numerous studies have indicated that the temporal variation in the $\mathrm{CH}_{4}$ flux is mainly determined by temperature, and the $\mathrm{CH}_{4}$ flux increases with increasing temperature $[83,84]$. At our study site, there was a negative correlation (Figure $6, p<0.01, R^{2}=0.34$ ) between $\mathrm{T}_{\text {soil } 10}$ and the $\mathrm{CH}_{4}$ flux, which was different from the results of many previous studies $[42,80,85,86]$. That is because, in winter, despite the lower soil temperature, the soil moisture in the study was highest, and the relatively favorable wet conditions were suitable for enhancing $\mathrm{CH}_{4}$ production. In summer, a higher soil temperature may result in more $\mathrm{CH}_{4}$ consumption, forming an enhanced sink of $\mathrm{CH}_{4}$ (Figure 5).

There is general agreement among mainstream scientists that soil moisture plays an important role in ecosystem $\mathrm{CH}_{4}$ exchange $[13,84,87]$. Soil moisture can directly affect oxygen availability, gas diffusion rate and microbial activity, and that significantly alters $\mathrm{CH}_{4}$ oxidation and production $[28,88,89]$. In our study, $\mathrm{M}_{\text {soil } 10}$ had a significant positive effect on the $\mathrm{CH}_{4}$ flux (Figure $6 \mathrm{~b}, p<0.01$ ) and accounted for approximately $34.8 \%$ of the variation in the daily $\mathrm{CH}_{4}$ flux (Figure 6b). During the winter, the higher soil moisture should have created more anaerobic conditions for methanogens and thus increased $\mathrm{CH}_{4}$ emissions. However, in the summer, the lower soil moisture due to the higher temperature could form aerobic soil conditions to promote the uptake of $\mathrm{CH}_{4}$ via $\mathrm{CH}_{4}$ oxidation (Figure 7).
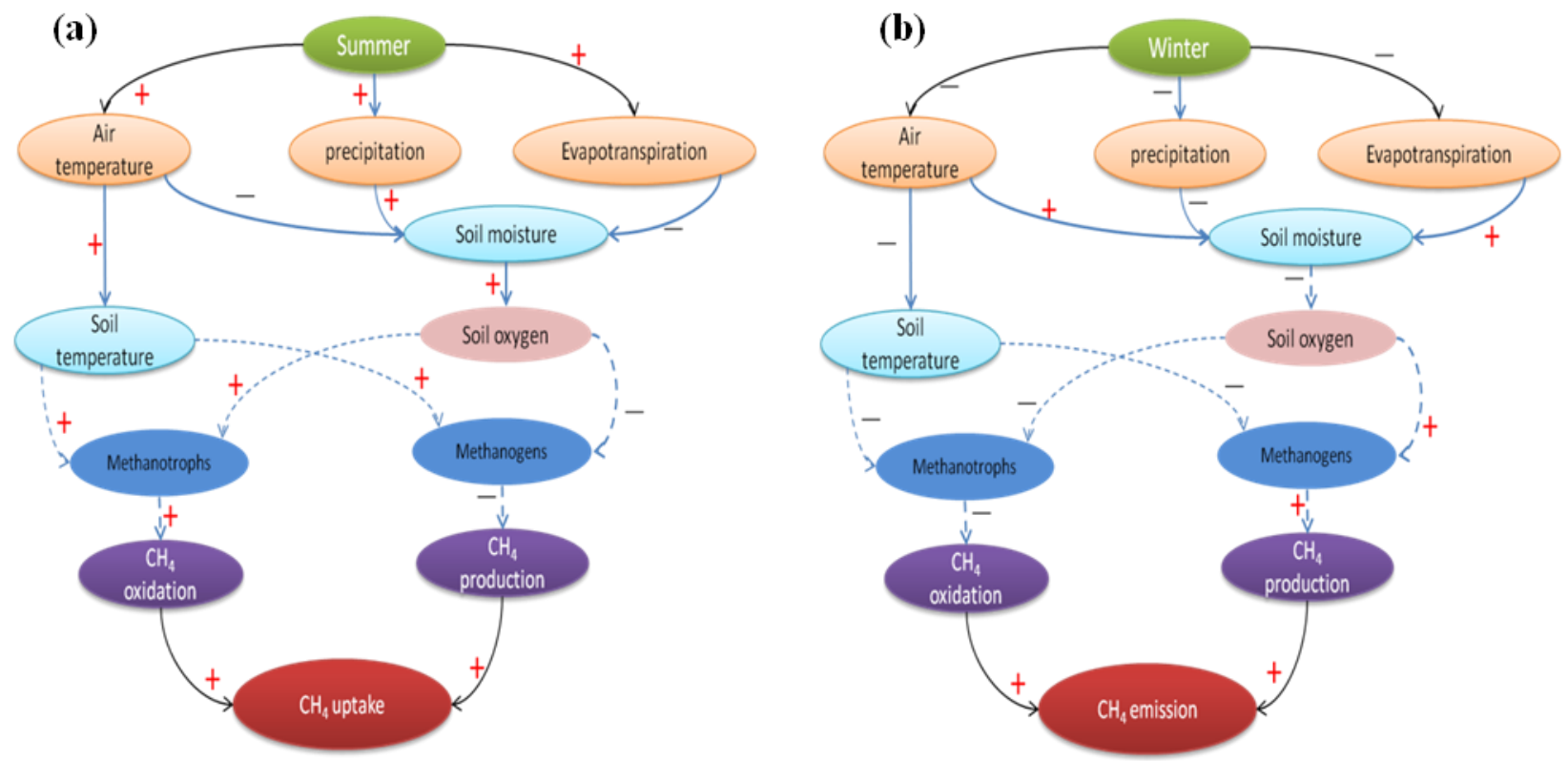

Figure 7. Mechanisms of methane uptake and emissions between summer (a) and winter (b). " + ", positive contribution or stimulation; "-", negative contribution or suppression. Since no measurement was made, the dotted line represents the possible effects. 
In addition, $\mathrm{CH}_{4}$ flux dynamics are affected by many other factors [15,17,19,20,90-92]. All of the abovementioned factors eventually combined and interacted to affect the processes and activities of methanotrophs and methanogens (Figure 7). In summer, the effect of soil temperature on methanotrophs may be more dominant than that of methanogens. Meanwhile, soil moisture decreased due to higher evapotranspiration. Adequate oxygen may weaken the activity of methanogens. However, in winter, due to high soil moisture, soil oxygen is relatively low, and anaerobic conditions may increase methane emissions (Figure 7).

Although both soil temperature and moisture are important factors influencing the sources and sinks of $\mathrm{CH}_{4}$, it was obvious in this study that the effect of soil moisture on the $\mathrm{CH}_{4}$ flux played a dominant role in the annual $\mathrm{CH}_{4}$ budget during the winter. Therefore, the $\mathrm{CH}_{4}$ emissions in winter were higher than the uptake in summer. It is likely that the reason for the higher soil moisture in winter may be due to snow cover [14,93-95]. On the one hand, the melting of snow water led to higher soil moisture and lower oxygen content, resulting in the reduction was more than that in summer, thus reducing the proportion of $\mathrm{CH}_{4}$ oxidation. On the other hand, snow cover can also keep the soil warm, thereby maintaining the activity of soil methanogens, increasing the production of $\mathrm{CH}_{4}$. Consequently, this may result in a positive $\mathrm{CH}_{4}$ annual budget (a net source of $\mathrm{CH}_{4}$ ), which provides direct evidence to support the previous model simulation study by Tian et al. [5].

Obviously, our current understanding, measurement data and analysis are still limited. First, several data gaps in the $\mathrm{CH}_{4}$ flux observations existed during the measurements because of instrument failure and a lack of electrical supply. For example, the data from March to June 2016 were missing due to a break in the electrical power supply. Although we used the random forest (RF) approach to gap-fill data, this gap-filling may have introduced some artificial bias and errors for annual budget estimation. Second, additional auxiliary measurements on soil microbial activities, soil oxygen, tree species, ages, tissue types and site characteristics are needed to improve our understanding of the mechanisms of $\mathrm{CH}_{4}$ uptake and emissions [8].

\section{Conclusions}

This study provides a first attempt to use the eddy covariance technique to continuously measure and quantify $\mathrm{CH}_{4}$ uptake, emissions and annual budget and to investigate its control factors in a subtropical forest of Zhejiang Province, China. Our results suggested that natural evergreen and deciduous broad-leaved forests in the study area acted as $\mathrm{CH}_{4}$ sinks (uptake of $-0.84 \mathrm{~g} \mathrm{~m}^{-2}$ year ${ }^{-1}$ ) in summer and $\mathrm{CH}_{4}$ sources (emissions of $3.815 \mathrm{~g}$ $\mathrm{CH}_{4} \mathrm{~m}^{-2}$ year ${ }^{-1}$ ) in winter. The net annual budget (net source) of $\mathrm{CH}_{4}$ was approximately 1.15-4.79 $\mathrm{g} \mathrm{m}^{-2}$ year ${ }^{-1}$ during 2017-2018, which provides positive feedback to global climate warming. We also observed a clear diurnal and seasonal pattern of $\mathrm{CH}_{4}$ flux. At the daily scale, there was a significant emission peak in winter and a significant uptake peak in summer. The peaks of emissions and uptake both occurred at noon. At the seasonal scale, the studied forest region acted as a $\mathrm{CH}_{4}$ source during winter and a sink in summer. Soil temperature and moisture are the most important and dominant factors affecting the $\mathrm{CH}_{4}$ dynamics of subtropical forests in China. In addition, this study filled the research gap of $\mathrm{CH}_{4}$ flux observations of upland forests at the ecosystem scale, providing unique field observation data for informing and validating simulations of process-based $\mathrm{CH}_{4}$ dynamic models for global upland forest $\mathrm{CH}_{4}$ budgets.

Author Contributions: Conceptualization, H.W., Z.L. and H.L.; methodology, H.W. and H.L.; software, H.W. and H.L.; validation, C.P. and H.L.; formal analysis, H.W.; investigation, H.W., Q.L. and J.L.; resources, C.P., X.S. and H.J.; data curation, H.W.; writing—original draft preparation, H.W.; writing-review and editing, C.P. and H.L.; project administration, C.P.; funding acquisition, C.P. All authors have read and agreed to the published version of the manuscript.

Funding: This research was funded by the National Key R\&D Program of China, grant number: 2016YFC050020. 
Data Availability Statement: The data presented in this study are available on reasonable request from the corresponding author. The data are not publicly available due to privacy.

Acknowledgments: We wish to acknowledge the Tianmu Mountain Nature Reserve Administration for help in field investigations.

Conflicts of Interest: The authors declare no conflict of interest.

\section{References}

1. Etminan, M.; Myhre, G.; Highwood, E.J.; Shine, K.P. Radiative forcing of carbon dioxide, methane, and nitrous oxide: A significant revision of the methane radiative forcing. Geophys. Res. Lett. 2016, 43, 12614-12623. [CrossRef]

2. Myhre, G.; Shindell, D.; Bréon, F.-M.; Collins, W.; Fuglestvedt, J.; Huang, J.; Douglas Dounald Koch, M.D.; Lamarque, J.-F.; Lee, D.; Mendoza, B.; et al. Anthropogenic and Natural Radiative Forcing. In Climatechange 2013: The Physical Science Basis. Contribution of Working Group I to the Fifth Assessment Report of the Intergovernmental Panel on Climate Change; Stocker, T.F., Qin, D., Eds.; Cambridge University Press: Cambridge, UK; New York, NY, USA, 2013; pp. 659-740, 1535.

3. Dlugokencky, E.J.; Bruhwiler, L.; White, J.W.C.; Emmons, L.K.; Novelli, P.C.; Montzka, S.A.; Masarie, K.A.; Lang, P.M.; Crotwell, A.M.; Miller, J.B.; et al. Observational constraints on recent increases in the atmospheric $\mathrm{CH}_{4}$ burden. Geophys. Res. Lett. 2009, 36, L18803. [CrossRef]

4. Kirschke, S.; Bousquet, P.; Ciais, P.; Saunois, M.; Canadell, J.G.; Dlugokencky, E.J.; Bergamaschi, P.; Bergmann, D.; Blake, D.R.; Bruhwiler, L.; et al. Three decades of global methane sources and sinks. Nat. Geosci. 2013, 6, 813-823. [CrossRef]

5. Tian, H.Q.; Lu, C.Q.; Ciais, P.; Michalak, A.M.; Canadell, J.G.; Saikawa, E.; Huntzinger, D.N.; Gurney, K.R.; Sitch, S.; Zhang, B.W.; et al. The terrestrial biosphere as a net source of greenhouse gases to the atmosphere. Nature 2016, 531, 225-228. [CrossRef]

6. Saunois, M.; Stavert, A.R.; Poulter, B.; Bousquet, P.; Canadell, J.G.; Jackson, R.B.; Raymond, P.A.; Dlugokencky, E.J.; Houweling, S.; Patra, P.K.; et al. The Global Methane Budget 2000-2017. Earth Syst. Sci. Data 2020, 12, 1561-1623. [CrossRef]

7. Dlugokencky, E.J.; Nisbet, E.G.; Fisher, R.; Lowry, D. Global atmospheric methane: Budget, changes and dangers. Philos. Trans. R. Soc. A Math. Phys. Eng. Sci. 2011, 369, 2058-2072. [CrossRef]

8. Covey, K.R.; Megonigal, J.P. Methane production and emissions in trees and forests. New Phytol. 2019, 222, 35-51. [CrossRef] [PubMed]

9. Ni, X.Y.; Groffman, P.M. Declines in methane uptake in forest soils. Proc. Natl. Acad. Sci. USA 2018, 115, 8587-8590. [CrossRef]

10. Xiang, W.H.; Zhou, J.; Ouyang, S.; Zhang, S.L.; Lei, P.F.; Li, J.X.; Deng, X.W.; Fang, X.; Forrester, D.I. Species-specific and general allometric equations for estimating tree biomass components of subtropical forests in southern China. Eur. J. For. Res. 2016, 135, 963-979. [CrossRef]

11. Xu, L.; Shi, Y.J.; Fang, H.Y.; Zhou, G.M.; Xu, X.J.; Zhou, Y.F.; Tao, J.X.; Ji, B.Y.; Xu, J.; Li, C.; et al. Vegetation carbon stocks driven by canopy density and forest age in subtropical forest ecosystems. Sci. Total Environ. 2018, 631-632, 619-626. [CrossRef]

12. Ouyang, S.; Xiang, W.H.; Wang, X.P.; Xiao, W.F.; Chen, L.; Li, S.G.; Sun, H.; Deng, X.W.; Forrester, D.I.; Zeng, L.X.; et al. Effects of stand age, richness and density on productivity in subtropical forests in China. J. Ecol. 2019, 107, 2266-2277. [CrossRef]

13. Feng, H.L.; Guo, J.H.; Han, M.H.; Wang, W.F.; Peng, C.H.; Jin, J.X.; Song, X.Z.; Yu, S.Q. A review of the mechanisms and controlling factors of methane dynamics in forest ecosystems. For. Ecol. Manag. 2020, 455, 117702. [CrossRef]

14. Blanc-Betes, E.; Welker, J.M.; Sturchio, N.C.; Chanton, J.P.; Gonzalez-Meler, M.A. Winter precipitation and snow accumulation drive the methane sink or source strength of Arctic tussock tundra. Glob. Chang. Biol. 2016, 22, 2818-2833. [CrossRef]

15. Kim, Y. Effect of thaw depth on fluxes of $\mathrm{CO}_{2}$ and $\mathrm{CH}_{4}$ in manipulated Arctic coastal tundra of Barrow, Alaska. Sci. Total Environ. 2015, 505, 385-389. [CrossRef] [PubMed]

16. Wang, H.; Yu, L.F.; Zhang, Z.H.; Liu, W.; Chen, L.T.; Cao, G.M.; Yue, H.W.; Zhou, J.Z.; Yang, Y.F.; Tang, Y.H.; et al. Molecular mechanisms of water table lowering and nitrogen deposition in affecting greenhouse gas emissions from a Tibetan alpine wetland. Glob. Chang. Biol. 2017, 23, 815-829. [CrossRef]

17. Morin, T.H.; Bohrer, G.; Frasson, R.; Naor-Azreli, L.; Mesi, S.; Stefanik, K.C.; Schafer, K.V.R. Environmental drivers of methane fluxes from an urban temperate wetland park. J. Geophys. Res. Biogeosci. 2014, 119, 2188-2208. [CrossRef]

18. Wu, J.J.; Lu, M.; Fenga, J.; Zhang, D.D.; Chen, Q.; Li, Q.X.; Long, C.Y.; Zhang, Q.F.; Cheng, X.L. Soil net methane uptake rates in response to short-term litter input change in a coniferous forest ecosystem of central China. Agric. Forest Meteorol. 2019, 271, 307-315. [CrossRef]

19. Hatala, J.A.; Detto, M.; Baldocchi, D.D. Gross ecosystem photosynthesis causes a diurnal pattern in methane emission from rice. Geophys. Res. Lett. 2012, 39, L06409. [CrossRef]

20. Whiting, G.J.; Chanton, J.P. Plant-dependent $\mathrm{CH}_{4}$ emission in a subarctic canadian fen. Glob. Biogeochem. Cycle 1992, 6, $225-231$. [CrossRef]

21. Bergman, I.; Svensson, B.H.; Nilsson, M. Regulation of methane production in a Swedish acid mire by $\mathrm{pH}$, temperature and substrate. Soil Biol. Biochem. 1998, 30, 729-741. [CrossRef]

22. Suyker, A.E.; Verma, S.B.; Clement, R.J.; Billesbach, D.P. Methane flux in a boreal fen: Season-long measurement by eddy correlation. J. Geophys. Res. Atmos. 1996, 101, 28637-28647. [CrossRef] 
23. Updegraff, K.; Bridgham, S.D.; Pastor, J.; Weishampel, P.; Harth, C. Response of $\mathrm{CO}_{2}$ and $\mathrm{CH}_{4}$ emissions from peatlands to warming and water table manipulation. Ecol. Appl. 2001, 11, 311-326. [CrossRef]

24. Weiss, R.; Shurpali, N.J.; Sallantaus, T.; Laiho, R.; Laine, J.; Alm, J. Simulation of water table level and peat temperatures in boreal peatlands. Ecol. Model. 2006, 192, 441-456. [CrossRef]

25. Funk, D.W.; Pullman, E.R.; Peterson, K.M.; Crill, P.M.; Billings, W.D. Influence of water-table on carbon-dioxide, carbon-monoxide, and methane fluxes from taiga bog microcosms. Glob. Biogeochem. Cycle 1994, 8, 271-278. [CrossRef]

26. Moore, T.R.; Knowles, R. The influence of water table levels on methane and carbon dioxide emissions from peatland soils. Can. J. Soil Sci. 1989, 69, 33-38. [CrossRef]

27. Davidson, E.A.; Belk, E.; Boone, R.D. Soil water content and temperature as independent or confounded factors controlling soil respiration in a temperate mixed hardwood forest. Glob. Chang. Biol. 1998, 4, 217-227. [CrossRef]

28. Le Mer, J.; Roger, P. Production, oxidation, emission and consumption of methane by soils: A review. Eur. J. Soil Biol. 2001, 37, 25-50. [CrossRef]

29. Hosono, T.; Nouchi, I. The dependence of methane transport in rice plants on the root zone temperature. Plant. Soil 1997, 191, 233-240. [CrossRef]

30. Kallistova, A.Y.; Merkel, A.Y.; Tarnovetskii, I.Y.; Pimenov, N.V. Methane Formation and Oxidation by Prokaryotes. Microbiology 2017, 86, 661-683. [CrossRef]

31. Koh, H.S.; Ochs, C.A.; Yu, K.W. Hydrologic gradient and vegetation controls on $\mathrm{CH}_{4}$ and $\mathrm{CO}_{2}$ fluxes in a spring-fed forested wetland. Hydrobiologia 2009, 630, 271-286. [CrossRef]

32. Lai, D.Y.F. Methane Dynamics in Northern Peatlands: A Review. Pedosphere 2009, 19, 409-421. [CrossRef]

33. Dong, Y.S.; Qi, Y.C.; Luo, J.; Liang, T.; Luo, K.L.; Zhang, S. Experimental study on $\mathrm{N}_{2} \mathrm{O}$ and $\mathrm{CH}_{4}$ fluxes from the dark coniferous forest zone soil of the Gongga Mountain, China. Sci. China Ser. D Earth Sci. 2003, 46, 285-295. [CrossRef]

34. Liu, X.; Yang, Z.; Lie, J.; Yi, L.; Yang, Y. Effects of Forest Conversion on $\mathrm{CH}_{4}$ Oxidation Rates in Mid-Subtropics. Sci. Silvae Sin. 2012, 48, 7-12. [CrossRef]

35. Werner, C.; Zheng, X.H.; Tang, J.W.; Xie, B.H.; Liu, C.Y.; Kiese, R.; Butterbach-Bahl, $\mathrm{K}^{\mathrm{N}} \mathrm{N}_{2} \mathrm{O}, \mathrm{CH}_{4}$ and $\mathrm{CO}_{2}$ emissions from seasonal tropical rainforests and a rubber plantation in Southwest China. Plant. Soil 2006, 289, 335-353. [CrossRef]

36. Yang, X.T.; Wang, C.M.; Xu, K. Response of soil $\mathrm{CH}_{4}$ fluxes to stimulated nitrogen deposition in a temperate deciduous forest in northern China: A 5-year nitrogen addition experiment. Eur. J. Soil Biol. 2017, 82, 43-49. [CrossRef]

37. Lohila, A.; Aalto, T.; Aurela, M.; Hatakka, J.; Tuovinen, J.P.; Kilkki, J.; Penttila, T.; Vuorenmaa, J.; Hanninen, P.; Sutinen, R.; et al. Large contribution of boreal upland forest soils to a catchment-scale $\mathrm{CH}_{4}$ balance in a wet year. Geophys. Res. Lett. 2016, 43, 2946-2953. [CrossRef]

38. Savi, F.; Di Bene, C.; Canfora, L.; Mondini, C.; Fares, S. Environmental and biological controls on $\mathrm{CH}_{4}$ exchange over an evergreen Mediterranean forest. Agric. For. Meteorol. 2016, 226, 67-79. [CrossRef]

39. Whiting, G.J.; Chanton, J.P. Primary production control of methane emission from wetlands. Nature 1993, 364, 794-795. [CrossRef]

40. Baldocchi, D.; Falge, E.; Gu, L.H.; Olson, R.; Hollinger, D.; Running, S.; Anthoni, P.; Bernhofer, C.; Davis, K.; Evans, R.; et al. FLUXNET: A new tool to study the temporal and spatial variability of ecosystem-scale carbon dioxide, water vapor, and energy flux densities. Bull. Am. Meteorol. Soc. 2001, 82, 2415-2434. [CrossRef]

41. Baldocchi, D.D. How eddy covariance flux measurements have contributed to our understanding of Global Change Biology. Glob. Chang. Biol. 2020, 26, 242-260. [CrossRef] [PubMed]

42. Li, H.; Dai, S.Q.; Ouyang, Z.T.; Xie, X.; Guo, H.Q.; Gu, C.H.; Xiao, X.M.; Ge, Z.M.; Peng, C.H.; Zhao, B. Multi-scale temporal variation of methane flux and its controls in a subtropical tidal salt marsh in eastern China. Biogeochemistry 2018, 137, 163-179. [CrossRef]

43. Petrescu, A.M.R.; Lohila, A.; Tuovinen, J.P.; Baldocchi, D.D.; Desai, A.R.; Roulet, N.T.; Vesala, T.; Dolman, A.J.; Oechel, W.C.; Marcolla, B.; et al. The uncertain climate footprint of wetlands under human pressure. Proc. Natl. Acad. Sci. USA 2015, 112, 4594-4599. [CrossRef]

44. Song, W.M.; Wang, H.; Wang, G.S.; Chen, L.T.; Jin, Z.N.; Zhuang, Q.L.; He, J.S. Methane emissions from an alpine wetland on the Tibetan Plateau: Neglected but vital contribution of the nongrowing season. J. Geophys. Res. Biogeosci. 2015, 120, 1475-1490. [CrossRef]

45. Deshmukh, C.S.; Julius, D.; Evans, C.D.; Susanto, A.P.; Page, S.E.; Gauci, V.; Lauren, A.; Sabiham, S.; Agus, F.; Asyhari, A.; et al. Impact of forest plantation on methane emissions from tropical peatland. Glob. Chang. Biol. 2020, 26, 2477-2495. [CrossRef] [PubMed]

46. Sakabe, A.; Itoh, M.; Hirano, T.; Kusin, K. Ecosystem-scale methane flux in tropical peat swamp forest in Indonesia. Glob. Chang. Biol. 2018, 24, 5123-5136. [CrossRef]

47. Yu, X.Y.; Song, C.C.; Sun, L.; Wang, X.W.; Shi, F.X.; Cui, Q.; Tan, W.W. Growing season methane emissions from a permafrost peatland of northeast China: Observations using open-path eddy covariance method. Atmos. Environ. 2017, 153, 135-149. [CrossRef]

48. Knox, S.H.; Matthes, J.H.; Sturtevant, C.; Oikawa, P.Y.; Verfaillie, J.; Baldocchi, D. Biophysical controls on interannual variability in ecosystem-scale $\mathrm{CO}_{2}$ and $\mathrm{CH}_{4}$ exchange in a California rice paddy. J. Geophys. Res. Biogeosci. 2016, 121, 978-1001. [CrossRef] 
49. Li, H.; Guo, H.Q.; Helbig, M.; Dai, S.Q.; Zhang, M.S.; Zhao, M.; Peng, C.H.; Xiao, X.M.; Zhao, B. Does direct-seeded rice decrease ecosystem-scale methane emissions?-A case study from a rice paddy in southeast China. Agric. For. Meteorol. 2019, 272, 118-127. [CrossRef]

50. Fest, B.; Hinko-Najera, N.; von Fischer, J.C.; Livesley, S.J.; Arndt, S.K. Soil Methane Uptake Increases under Continuous Throughfall Reduction in a Temperate Evergreen, Broadleaved Eucalypt Forest. Ecosystems 2017, 20, 368-379. [CrossRef]

51. Knox, S.H.; Jackson, R.B.; Poulter, B.; McNicol, G.; Fluet-Chouinard, E.; Zhang, Z.; Hugelius, G.; Bousquet, P.; Canadell, J.G.; Saunois, M.; et al. FLUXNET-CH 4 Synthesis Activity: Objectives, Observations, and Future Directions. Bull. Amer. Meteorol. Soc. 2019, 100, 2607-2632. [CrossRef]

52. Shoemaker, J.K.; Keenan, T.F.; Hollinger, D.Y.; Richardson, A.D. Forest ecosystem changes from annual methane source to sink depending on late summer water balance. Geophys. Res. Lett. 2014, 41, 673-679. [CrossRef]

53. Nakai, T.; Shimoyama, K. Ultrasonic anemometer angle of attack errors under turbulent conditions. Agric. For. Meteorol. 2012, 162, 14-26. [CrossRef]

54. Webb, E.K.; Pearman, G.I.; Leuning, R. Correction of flux measurements for density effects due to heat and water vapour transfer. Q. J. R. Meteorol. Soc. 1980, 106, 85-100. [CrossRef]

55. Foken, T.; Göockede, M.; Mauder, M.; Mahrt, L.; Amiro, B.; Munger, W. Post-Field Data Quality Control. In Handbook of Micrometeorology: A Guide for Surface Flux Measurement and Analysis; Lee, X., Massman, W., Eds.; Springer: Dordrecht, The Netherlands, 2005; pp. 181-208.

56. Vickers, D.; Mahrt, L. Quality control and flux sampling problems for tower and aircraft data. J. Atmos. Ocean. Technol. 1997, 14, 512-526. [CrossRef]

57. Reichstein, M.; Falge, E.; Baldocchi, D.; Papale, D.; Aubinet, M.; Berbigier, P.; Bernhofer, C.; Buchmann, N.; Gilmanov, T.; Granier, A.; et al. On the separation of net ecosystem exchange into assimilation and ecosystem respiration: Review and improved algorithm. Glob. Chang. Biol. 2005, 11, 1424-1439. [CrossRef]

58. Breiman, L. Random forests. Mach. Learn. 2001, 45, 5-32. [CrossRef]

59. Kim, Y.; Johnson, M.S.; Knox, S.H.; Black, T.A.; Dalmagro, H.J.; Kang, M.; Kim, J.; Baldocchi, D. Gap-filling approaches for eddy covariance methane fluxes: A comparison of three machine learning algorithms and a traditional method with principal component analysis. Glob. Chang. Biol. 2020, 26, 1499-1518. [CrossRef]

60. Finkelstein, P.L.; Sims, P.F. Sampling error in eddy correlation flux measurements. J. Geophys. Res. Atmos. 2001, 106, 3503-3509. [CrossRef]

61. Dong-mei, X.; Miao, W.; Yue-si, W.; Lan-zhu, J.; Shi-jie, H. Fluxes of soil carbon dioxide, nitrous oxide and firedamp in broadleaved/Korean pine forest. J. For. Res. 2004, 15, 107-112. [CrossRef]

62. Ma, X.Z.; Zhang, Q.L.; Li, C.S.; Chen, G.W.; Wang, F. Temporal variation of soil greenhouse gases fluxes in a cold-temperate Larix gmelinii forest in Inner Mongolia, China. Chin. J. Appl. Ecol. 2012, 23, 2149-2156. [CrossRef]

63. Wang, J.M.; Murphy, J.G.; Geddes, J.A.; Winsborough, C.L.; Basiliko, N.; Thomas, S.C. Methane fluxes measured by eddy covariance and static chamber techniques at a temperate forest in central Ontario, Canada. Biogeosciences 2013, 10, 4371-4382. [CrossRef]

64. Querino, C.A.S.; Smeets, C.; Vigano, I.; Holzinger, R.; Moura, V.; Gatti, L.V.; Martinewski, A.; Manzi, A.O.; de Araujo, A.C.; Rockmann, T. Methane flux, vertical gradient and mixing ratio measurements in a tropical forest. Atmos. Chem. Phys. 2011, 11, 7943-7953. [CrossRef]

65. Chen, H.; Liu, X.W.; Xue, D.; Zhu, D.; Zhan, W.; Li, W.; Wu, N.; Yang, G. Methane emissions during different freezing-thawing periods from a fen on the Qinghai-Tibetan Plateau: Four years of measurements. Agric. For. Meteorol. 2021, 297, 108279. [CrossRef]

66. Morin, T.H.; Bohrer, G.; Naor-Azrieli, L.; Mesi, S.; Kenny, W.T.; Mitsch, W.J.; Schafer, K.V.R. The seasonal and diurnal dynamics of methane flux at a created urban wetland. Ecol. Eng. 2014, 72, 74-83. [CrossRef]

67. Sakabe, A.; Hamotani, K.; Kosugi, Y.; Ueyama, M.; Takahashi, K.; Kanazawa, A.; Itoh, M. Measurement of methane flux over an evergreen coniferous forest canopy using a relaxed eddy accumulation system with tuneable diode laser spectroscopy detection. Theor. Appl. Climatol. 2012, 109, 39-49. [CrossRef]

68. Sundqvist, E.; Molder, M.; Crill, P.; Kljun, N.; Lindroth, A. Methane exchange in a boreal forest estimated by gradient method. Tellus Ser. B Chem. Phys. Meteorol. 2015, 67, 26688. [CrossRef]

69. Borken, W.; Davidson, E.A.; Savage, K.; Sundquist, E.T.; Steudler, P. Effect of summer throughfall exclusion, summer drought, and winter snow cover on methane fluxes in a temperate forest soil. Soil Biol. Biochem. 2006, 38, 1388-1395. [CrossRef]

70. Castro, M.S.; Steudler, P.A.; Melillo, J.M.; Aber, J.D.; Millham, S. Exchange of $\mathrm{N}_{2} \mathrm{O}$ and $\mathrm{CH}_{4}$ between the atmosphere and soils in spruce-fir forests in the northeastern United-States. Biogeochemistry 1992, 18, 119-135. [CrossRef]

71. Liu, J.; Zhou, Y.; Valach, A.; Shortt, R.; Kasak, K.; Rey-Sanchez, C.; Hemes, K.S.; Baldocchi, D.; Lai, D.Y.F. Methane emissions reduce the radiative cooling effect of a subtropical estuarine mangrove wetland by half. Glob. Chang. Biol. 2020, 26, 4998-5016. [CrossRef]

72. Mo, J.M.; Fang, Y.T.; Li, D.J.; Lin, E.D.; Li, Y.E. Soil $\mathrm{CO}_{2}$ emission and $\mathrm{CH}_{4}$ uptake in the main forests of Dinghushan in subtropical China. Guihaia 2006, 26, 142-147. [CrossRef]

73. Tang, X.L.; Liu, S.G.; Zhou, G.Y.; Zhang, D.Q.; Zhou, C.Y. Soil-atmospheric exchange of $\mathrm{CO}_{2}, \mathrm{CH}_{4}$, and $\mathrm{N}_{2} \mathrm{O}$ in three subtropical forest ecosystems in southern China. Glob. Chang. Biol. 2006, 12, 546-560. [CrossRef] 
74. Morishita, T.; Sakata, T.; Takahashi, M.; Ishizuka, S.; Mizoguchi, T.; Inagaki, Y.; Terazawa, K.; Sawata, S.; Igarashi, M.; Yasuda, H.; et al. Methane uptake and nitrous oxide emission in Japanese forest soils and their relationship to soil and vegetation types. Soil Sci. Plant. Nutr. 2007, 53, 678-691. [CrossRef]

75. Smith, K.A.; Dobbie, K.E.; Ball, B.C.; Bakken, L.R.; Sitaula, B.K.; Hansen, S.; Brumme, R.; Borken, W.; Christensen, S.; Prieme, A.; et al. Oxidation of atmospheric methane in Northern European soils, comparison with other ecosystems, and uncertainties in the global terrestrial sink. Glob. Chang. Biol. 2000, 6, 791-803. [CrossRef]

76. Dalmagro, H.J.; de Arruda, P.H.Z.; Vourlitis, G.L.; Lathuilliere, M.J.; Nogueira, J.D.; Couto, E.G.; Johnson, M.S. Radiative forcing of methane fluxes offsets net carbon dioxide uptake for a tropical flooded forest. Glob. Chang. Biol. 2019, 25, 1967-1981. [CrossRef]

77. Tveit, A.T.; Hestnes, A.G.; Robinson, S.L.; Schintlmeister, A.; Dedysh, S.N.; Jehmlich, N.; von Bergen, M.; Herbold, C.; Wagner, M.; Richter, A.; et al. Widespread soil bacterium that oxidizes atmospheric methane. Proc. Natl. Acad. Sci. USA 2019, 116, 8515-8524. [CrossRef]

78. Bubier, J.L.; Moore, T.R. An ecological perspective on methane emissions from northern wetlands. Trends Ecol. Evol. 1994, 9, 460-464. [CrossRef]

79. Euskirchen, E.S.; Edgar, C.W.; Turetsky, M.R.; Waldrop, M.P.; Harden, J.W. Differential response of carbon fluxes to climate in three peatland ecosystems that vary in the presence and stability of permafrost. J. Geophys. Res. Biogeosci. 2014, 119, 1576-1595. [CrossRef]

80. Keppler, F.; Hamilton, J.T.G.; Brass, M.; Rockmann, T. Methane emissions from terrestrial plants under aerobic conditions. Nature 2006, 439, 187-191. [CrossRef]

81. Rinne, J.; Riutta, T.; Pihlatie, M.; Aurela, M.; Haapanala, S.; Tuovinen, J.P.; Tuittila, E.S.; Vesala, T. Annual cycle of methane emission from a boreal fen measured by the eddy covariance technique. Tellus Ser. B Chem. Phys. Meteorol. 2007, 59, 449-457. [CrossRef]

82. Deng, Y.C.; Liu, P.F.; Conrad, R. Effect of temperature on the microbial community responsible for methane production in alkaline NamCo wetland soil. Soil Biol. Biochem. 2019, 132, 69-79. [CrossRef]

83. Schimel, J.P.; Gulledge, J. Microbial community structure and global trace gases. Glob. Chang. Biol. 1998, 4, 745-758. [CrossRef]

84. Song, C.C.; Xu, X.F.; Tian, H.Q.; Wang, Y.Y. Ecosystem-atmosphere exchange of $\mathrm{CH}_{4}$ and $\mathrm{N}_{2} \mathrm{O}$ and ecosystem respiration in wetlands in the Sanjiang Plain, Northeastern China. Glob. Chang. Biol. 2009, 15, 692-705. [CrossRef]

85. Wille, C.; Kutzbach, L.; Sachs, T.; Wagner, D.; Pfeiffer, E.M. Methane emission from Siberian arctic polygonal tundra: Eddy covariance measurements and modeling. Glob. Chang. Biol. 2008, 14, 1395-1408. [CrossRef]

86. Helbig, M.; Chasmer, L.E.; Kljun, N.; Quinton, W.L.; Treat, C.C.; Sonnentag, O. The positive net radiative greenhouse gas forcing of increasing methane emissions from a thawing boreal forest-wetland landscape. Glob. Chang. Biol. 2017, 23, 2413-2427. [CrossRef]

87. Hommeltenberg, J.; Mauder, M.; Drosler, M.; Heidbach, K.; Werle, P.; Schmid, H.P. Ecosystem scale methane fluxes in a natural temperate bog-pine forest in southern Germany. Agric. For. Meteorol. 2014, 198, 273-284. [CrossRef]

88. Ding, W.X.; Cai, Z.C.; Tsuruta, H.; Li, X.P. Key factors affecting spatial variation of methane emissions from freshwater marshes. Chemosphere 2003, 51, 167-173. [CrossRef]

89. Bender, M.; Conrad, R. Effect of $\mathrm{CH}_{4}$ concentrations and soil conditions on the induction of $\mathrm{CH}_{4}$ oxidation activity. Soil Biol. Biochem. 1995, 27, 1517-1527. [CrossRef]

90. Ge, H.X.; Zhang, H.S.; Zhang, H.; Cai, X.H.; Song, Y.; Kang, L. The characteristics of methane flux from an irrigated rice farm in East China measured using using the eddy covariance method. Agric. For. Meteorol. 2018, 249, 228-238. [CrossRef]

91. Wagner, D.; Lipski, A.; Embacher, A.; Gattinger, A. Methane fluxes in permafrost habitats of the Lena Delta: Effects of microbial community structure and organic matter quality. Environ. Microbiol. 2005, 7, 1582-1592. [CrossRef]

92. Metje, M.; Frenzel, P. Methanogenesis and methanogenic pathways in a peat from subarctic permafrost. Environ. Microbiol. 2007, 9, 954-964. [CrossRef] [PubMed]

93. Moore, T.R.; Dalva, M. The influence of temperature and water-table position on carbon-dioxide and methane emissions from laboratory columns of peatland soils. J. Soil Sci. 1993, 44, 651-664. [CrossRef]

94. Brandt, A.C.; Zhang, Q.Q.; Caceres, M.L.L.; Murayama, H. Soil temperature and soil moisture dynamics in winter and spring under heavy snowfall conditions in North-Eastern Japan. Hydrol. Process. 2020, 34, 3235-3251. [CrossRef]

95. West, A.E.; Brooks, P.D.; Fisk, M.C.; Smith, L.K.; Holland, E.A.; Jaeger, C.H.; Babcock, S.; Lai, R.S.; Schmidt, S.K. Landscape patterns of $\mathrm{CH}_{4}$ fluxes in an alpine tundra ecosystem. Biogeochemistry 1999, 45, 243-264. [CrossRef] 